\title{
DEVELOPMENT OF GLASS-CERAMIC HIGH-STREN GTH MATERIAL FOR PERSONAL ARMOR PROTECTION ELEMENTS
}

\author{
Oksana Savvova ${ }^{1, *}$, Luidmyla Bragina ${ }^{1}$, Gennadii Voronov$^{1}$, Yuliya Sobol ${ }^{1}$, \\ Olena Babich ${ }^{1}$, Oksana Shalygina ${ }^{1}$, M ykola Kuriakin ${ }^{1}$
}

https://doi.org/10.23939/chcht11.02.214

\begin{abstract}
The perspective of glass-ceramic high-strength materials used for personal armor elements has been established. The methodological approach has been developed and the choice of initial lithium aluminosilicate system for obtaining high-strength lightweight glassceramic materials has been substantiated. The glass formation area in the chosen system was studied, and model glasses were synthesized. Features of crystal structure formation during heat treatment of the developed model glasses were investigated. As a result, high-strength glass-ceramic materials have been developed. It has been determined that they possess high performance characteristics and can be used in manufacturing of modern composite armor.
\end{abstract}

Keywords: glass ceramic material, lithium aluminosilicate system, high-strength, mechanical properties, personal armor protection element.

\section{Introduction}

Rapid developments in the field of explosive substances, armaments and small-arm weapons contribute to the growth of ballistic risks faced by military and lawenforcement personnel. It is the reason for an urgent need in reliable and advanced materials for production of personal armor elements which provide increased level of their armor protection, and therefore save people's lives in conflict zones. Considering aforementioned, the studies aimed at finding and development of new high-strength lightweight materials are relevant.

Currently, various materials are being developed and used for manufacturing of armor protection elements. Specifically, flexible textile armor consisting of highmodulus and high-strength polyaramide or polyethylene

\footnotetext{
${ }^{1}$ National Technical University "Kharkiv Polytechnic Institute", 21 Frunze St., 61002 Kharkiv, Ukraine

savvova_oksana@ukr.net

(C) Savvova O., Bragina L., Voronov G., Sobol Yu., Babich O., Shalygina O., Kuriakin M., 2017
}

fabrics or fibers is widely used for protection from lowenergy weapons, such as melee weapons, revolver and pistol bullets [1]. Effective protection against high-energy weapons with high penetrative power, e.g. armor piercing rifle bullets with heat-treated slugs $\left(5^{\text {th }}\right.$ and $6^{\text {th }}$ classes according to Ukrainian standard DSTU V 4103-2002), is impossible without the use of hard elements like metallic alloys, ceramic and glass-ceramic materials (Table 1). The most notable of them are: high-strength armor steels MARS 300 (France), ARMOX 600S (Sweden), XH-206 (Germany), 44S (Russian Federation) [2], functional gradient materials (Italy) [3]; armor ceramics (Russian Federation) [4], glass-ceramic materials (Great Britain) [5].

Among the works dedicated to the synthesis problems of high-strength ceramic materials for personal protection there are a number of solid works by the scientists from Ukrainian institutions: National Technical University of Ukraine "Kyiv Polytechnic Institute" (NTUU "KPI") [10], Frantsevich Institute for Problems of Materials Science [11], "Keramtech LTD", Ukrainian State University of Railway Transport, V. Bakul Institute for Superhard Materials of NASU [12] and National Technical University "Kharkiv Polytechnic Institute" (NTU “KhPI”) [13, 14].

Technology of ceramic-metallic materials with titanium matrix reinforced by ceramic titanium boride fibers, characterized by a tensile strength of $890 \mathrm{MPa}$ and plasticity of more than $15 \%$, developed by NTUU "KPI" in cooperation with EO Paton Electric Welding Institute is of great interest. Moreover, they have developed a new generation of versatile superhard reinforced ceramics with armor protection class of 6 . This product is both advanced and readily marketable in current conditions [10].

IPM NASU has also contributed significantly to design, technological development and adjustment of the production of armored ceramic-polymer items. Also, for the first time in Ukraine they have created the manufacturing line for production of mosaic-structured ceramic-polymer armor blocks using method of reaction sintering of silicon carbide ceramics. [11]. 
Characteristics of armor protection

\begin{tabular}{|c|c|c|c|c|c|c|c|}
\hline \multirow[b]{2}{*}{ Property } & \multicolumn{2}{|c|}{ Metallic alloys $[2,6]$} & \multicolumn{3}{|c|}{ Ceramics $[2,3,7]$} & \multicolumn{2}{|c|}{ Glass-ceramics $[8,9]$} \\
\hline & $44 \mathrm{~S}$ & VT14 & $\mathrm{Al}_{2} \mathrm{O}_{3}$ & $\mathrm{~B}_{4} \mathrm{C}$ & $\mathrm{SiC}$ & \begin{tabular}{|c|} 
lithium \\
aluminosilicate
\end{tabular} & $\begin{array}{l}\text { lithium } \\
\text { silicate }\end{array}$ \\
\hline Density $\rho, \mathrm{kg} / \mathrm{m}^{3}$ & 7900 & 4520 & $3600-3900$ & $2450-2520$ & $3200-3300$ & 2410 & $2350-450$ \\
\hline TCLE, $\alpha \cdot 10^{7} \mathrm{~K}^{-1}$ & - & 87.0 & 84 & 55.4 & 51.2 & $5-17$ & $50-114$ \\
\hline Bending strength $\sigma_{\text {bend }}, \mathrm{MPa}$ & - & - & $200-400$ & $200-360$ & $600-730$ & $100-137$ & $38-40$ \\
\hline Bending strength $\sigma_{B}, \mathrm{MPa}$ & $2250-2350$ & $835-1300$ & - & - & - & - & - \\
\hline $\begin{array}{l}\text { Compressive strength } \\
\sigma_{\text {compress }}, \mathrm{GPa} \\
\end{array}$ & - & - & $2.07-6.6$ & $2.9-6.97$ & $1.7-5.84$ & - & - \\
\hline Tensile strength $\sigma_{\text {tens }}, \mathrm{MPa}$ & - & - & $260-300$ & 155 & 310 & - & - \\
\hline \multirow{2}{*}{$\begin{array}{l}\text { Hardness } \\
H V, \mathrm{GPa} \\
H B, \mathrm{MPa} \\
\end{array}$} & - & - & $12-18$ & $29-36$ & 28 & - & 5.8 \\
\hline & $55-57$ & $25.5-38.8$ & - & - & - & - & - \\
\hline Microhardness $H, \mathrm{MPa}$ & - & - & - & - & - & 57009300 & 6800 \\
\hline Young's modulus $E, \mathrm{MPa}$ & 216 & 110 & $300-450$ & $440-460$ & $440-476$ & $94-95$ & 94 \\
\hline Poisson ratio $\mu$ & - & - & 0.22 & 0.19 & 0.19 & 0.28 & 0.27 \\
\hline Sound velocity $c, \mathrm{~km} / \mathrm{s}$ & - & - & $9.5-11.6$ & $13.0-13.7$ & $11.2-12.0$ & $6.0-6.4$ & 6.0 \\
\hline Thermal conductivity $\lambda, \mathrm{W} / \mathrm{m} \cdot \mathrm{K}$ & - & 13.82 & 35 & 28 & 41 & $1.7-2.3$ & - \\
\hline Stress intensity $K_{l \mathrm{C}}, \mathrm{MPa} \cdot \mathrm{m}^{0.5}$ & - & - & 4.5 & 3.2 & 4.0 & - & $1.6-1.8$ \\
\hline Impact strength $\mathrm{KCU}, \mathrm{kJ} / \mathrm{m}^{2}$ & $50.0-60.0$ & $200-500$ & - & - & - & $2.2-6.0$ & - \\
\hline
\end{tabular}

Scientist of TOV "Keramtekh LTD" (Ukraine) have established manufacturing of experimental armor plate specimens using efficient high-density composite material on the base of refractory powders of oxides and carbides with high strength characteristics [12].

Studies conducted in NTU "KhPI" allowed to significantly improve characteristics and reliability of armor and aviation products by using valve metals with microarc oxidation treatment as the materials for elements of military vehicles, which can also be an effective mean of personal protection [14].

Analysis of currently available materials used as protective elements in bullet-proof vests in terms of performance and cost characteristics allowed to elicit their advantages and disadvantages.

While having functional efficiency, the armor steels and ceramic materials are heavy, which limits their use. The use of $\mathrm{B}_{4} \mathrm{C}$ ceramics with low density is limited by high costs and complexity of manufacturing technology. Titanium alloys are susceptible to localized shear plastic strains due to their low heat conductivity at intense dynamic load [2]. One of the solutions of this problem is development of high-strength lightweight glass-ceramic materials for the use in the elements of personal protection with high performance characteristics.

For that reason in Ukraine there exists a further need in studies related to technological development of relatively low-cost glass-ceramic materials.
The aim of the work is development of glassceramic high strength materials for the elements of personal protection.

\section{Experimental}

\subsection{Objectives and Research Methods}

To achieve the aim of the research the following objectives were set:

- to analyze best practices in developing of materials used as the elements of personal protection;

- to devise methodological approach for development of high strength glass-ceramic materials;

- to substantiate the choice of oxide system for obtaining glass-ceramic materials, investigate glass formation in it and synthesize model glasses;

- to determine the effect of phase composition on functional properties which provide high strength of the materials;

- to develop compositions of glass-ceramic materials for the elements of personal protection.

Following physico-chemical research methods, which allowed to investigate processes that take place during heat treatment, have been used in the work: differential-thermal (DTA), gradient-thermal, petrographic and dilatometric analysis methods. Values of 
mechanical characteristics were measured with PMT-3 and TMV-1000 hardness testers, and static-method elasticity tester.

\subsection{Development of M ethodological Approach for Obtaining $\mathrm{H}$ igh-Strength Lightweight Glass-Ceramic M aterials for Elements of Personal Armor}

The problem of obtaining a material for reliable personal protection creates the need to devise methodological approach consisting in determining a certain complex of requirements for the material being developed (Table 2) and its functional role.

Armor element must have two important properties: a high strength of surface layer, capable of breaking sharp nose of bullet slug, and required viscosity to absorb impact energy of bullet without formation of cracks and fracture [11].

Velocity of impact wave in armor material depends on its density and elasticity modulus. High velocity of advance of sound wave is important due to the following reasons: large area;

i) impact energy is quickly dissipated throughout a

ii) extent of projectile destruction increases.

The higher the difference between the velocity of sound wave in the projectile material and in the armor material, the more damage will the projectile receive. For ceramic materials, the velocity of sound wave increases with increasing elasticity modulus. However, for glassceramic materials the highest values of the velocity of sound wave belong to the compositions based on lithium aluminosilicates, elasticity modulus of which is 79-94 GPa. This can be attributed to the presence of vitreous phase in the structure of glass-ceramic materials, which provides relaxation of mechanical microstresses that occur due to thermal factors, and heal fractures that develop under impact. Presence of elastic glass matrix, which provides relaxation of stresses and dissipation of impact energy, allows to use this material not only as destructive, but also as damper layer. For this reason, brittle materials such as glass-ceramics have better protective action than it could have been expected on the base of simple calculations of the advance of sound wave.

Therefore, as a result of the combination of performance characteristics, glass-composite materials of glass-ceramic type can be used as a component of armor compositions "metal alloy (energy-destructive layer) ceramics (energy-destructive layer) - glass-ceramics (energy-destructive and energy-damping layer) - polymer (energy-damping layer)". Structural scheme of a composite armor element is shown in Fig. 1.

Achieving high values of strength and fracture viscosity in conjunction with low values of density and elasticity modulus of the armor elements can be provided by designing required initial composition of glasses and formation of nano- and microstructure of high-strength compounds in them during the low-temperature heat treatment. As a result, a significant number of fine crystals, which are partly intergrown, is formed. Main mechanisms of energy absorption and dissipation by glass ceramics consist in formation of significant number of new surfaces and finely fragmented particles of the material (up to $1 \mu \mathrm{m}$ in size), acceleration of fragmented mass and conduction of heat energy.

Table 2

Values of criteria for glass-ceramic materials determined according to standards

\begin{tabular}{|c|c|c|}
\hline Criteria & Value & Standard \\
\hline \multicolumn{3}{|l|}{ Physical properties } \\
\hline Density, $\mathrm{g} / \mathrm{cm}^{3}$ & $2.3-2.45$ & GOST 9553-74 \\
\hline Fracture toughness, MPa $\cdot \mathrm{m}^{0.5}$ & $2.5-4.0$ & GOST 25.506-85 \\
\hline Impact strength, $\mathrm{kJ} / \mathrm{m}^{2}$ & $5.0-6.0$ & GOST 11067-2013 (EN1288-1:2000) \\
\hline Bending strength, $\mathrm{MPa}$ & $400-500$ & GOST 32281.1-2013 \\
\hline Young's modulus, GPa & $80.0-120$ & GOST 9900-2013 \\
\hline $\begin{array}{l}\text { Hardness } \\
\text { Knoop } H K \\
\text { Vickers } H V, \mathrm{MPa}\end{array}$ & $\begin{array}{c}800-1000 \\
7000-8000\end{array}$ & GOST ISO 9385 \\
\hline Microhardness, MPa & $7000-8000$ & GOST 9450-76 \\
\hline Heat treatment temperature, $\mathrm{K}$ & $\leq 1073$ & \\
\hline Heat resistance, $\mathrm{K}$ & $1073-1273$ & GOST 4069-69 \\
\hline \multicolumn{3}{|l|}{ Penetration } \\
\hline Explosion resistance, class & ER1-ER4 & GOST 13541-2013 \\
\hline Bullet resistance, class & Br1-Br6 & GOST 32362-2013 \\
\hline Protection level of composite armor element, class & $4-5$ & DSTU B 4104-2002 \\
\hline Cost, USD/kg & less than 150 & \\
\hline
\end{tabular}




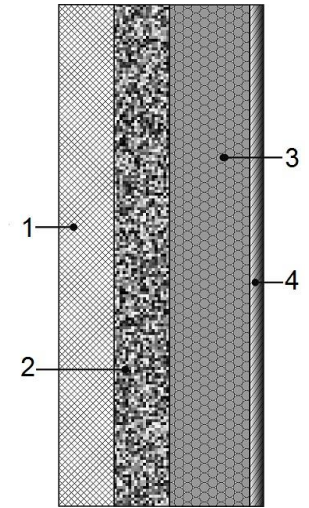

Fig. 1. Structural scheme of composite armor element: metal alloys (1); ceramics layer $\left(\mathrm{Al}_{2} \mathrm{O}_{3}, \mathrm{SiC}\right)(2)$;

layer of glass-ceramic material (spodumene, cordierite, anorthite glass ceramics) (3) and polymer layer (polyaramide fibers, ultra-high-molecular-weight polymer) (4)

Experimental embodiment of these provisions will allow the necessary armor rating (classes 4-6 according to Ukrainian standard DSTU V 4104-2002) by using armor glass ceramics as a part of composite armor element. Additionally, the mass and cost of such armor elements must be significantly lower than those of the fully ceramic armor elements.

\subsection{Choice of Core Oxide Systems and Synthesis of Model Glasses on their Base}

Distinguishing characteristic of glass ceramic materials is the combination of high mechanical strength needed for provision of resistance to the action of energydestructive constituents and ability to absorb and dissipate impact stresses with low density and relatively low cost.

It is known that thermal-resistant high-strength composite materials with high mechanical parameters, which may be used as armor elements, are obtained mainly on the base of spodumene and cordierite glass ceramics with thermal coefficient of linear expansion $\alpha=(1-125) \cdot 10^{-7} \mathrm{~K}^{-1}$, bending strength of $175-441 \mathrm{MPa}$, elasticity modulus $E=88-150 \mathrm{GPa}$ and hardness $H K=535-1100[8,15]$.

However, glass ceramic materials on the base of $\mathrm{MgO}-\mathrm{Al}_{2} \mathrm{O}_{3}-\mathrm{SiO}_{2}-\mathrm{TiO}_{2}$ system are characterized by higher values of density as opposed to the glass ceramic on the base of $\mathrm{Li}_{2} \mathrm{O}-\mathrm{Al}_{2} \mathrm{O}_{3}-\mathrm{SiO}_{2}-\mathrm{TiO}_{2}$ system, which prevents from obtaining low-weight glass ceramics on its base. In Ukraine the development of spodumene glass ceramics is mainly focused on materials for catalysts for ammonia oxidation [16].

To establish the field of occurrence of glasses for synthesis of lithium aluminosilicate materials for elements of personal armor the system $\mathrm{R}_{2} \mathrm{O}-\mathrm{RO}-\mathrm{RO}_{2}-\mathrm{R}_{2} \mathrm{O}_{3}-\mathrm{LiF}-$ $\mathrm{CaF}_{2}-\mathrm{P}_{2} \mathrm{O}_{5}-\mathrm{SiO}_{2}$ was chosen, where $\mathrm{R}_{2} \mathrm{O}-\mathrm{Na}_{2} \mathrm{O}, \mathrm{Li}_{2} \mathrm{O}$, $\mathrm{K} 2 \mathrm{O} ; \mathrm{RO}-\mathrm{CaO}, \mathrm{MgO}, \mathrm{ZnO} ; \mathrm{RO}_{2}-\mathrm{ZrO}_{2} \mathrm{TiO}_{2} ; \mathrm{R}_{2} \mathrm{O}_{3}-$ $\mathrm{Al}_{2} \mathrm{O}_{3}, \mathrm{~B}_{2} \mathrm{O}_{3}$. The glass formation area was confined and investigated in the experimental system, compositions of model glasses of SP series were synthesized as a base for obtaining spodumene glass-ceramic materials, and synthesized model glasses of SL series were a base for obtaining materials based on lithium disilicate.

Glasses of the aforementioned series were obtained by melting the glass batch consisting of conventional raw materials used in glass industry under identical conditions. The melting was carried out within the temperature range of $1523-1873 \mathrm{~K}$ in corundum crucibles with subsequent cooling of glass on a sheet of metal (Table 3). In the model glasses of SP and SL series the oxides were in ratios close to stoichiometric, which is required for crystallization of spodumene and lithium disilicate. Occurrence of these crystalline phases in the glass ceramic materials will provide their high performance characteristics.

In order to obtain the volume crystallized structure, conventional crystallization catalysts with different action mechanisms were used, viz. $\mathrm{TiO}_{2}, \mathrm{ZrO}_{2}$ and $\mathrm{LiF}$. Part of the model glasses contained certain amounts of $\mathrm{P}_{2} \mathrm{O}_{5}$ and $\mathrm{ZnO}$ so that the fine-crystalline interconnected structure could be formed. At the same time, the presence of $\mathrm{P}_{2} \mathrm{O}_{5}$ in the structure of glasses allows to decrease specimen's strain and stresses which occur upon absorption of impact energy.

Table 3

Technological parameters and characteristics of the main crystalline phase for developed glass crystalline materials

\begin{tabular}{|c|c|c|c|}
\hline \multirow{2}{*}{$\begin{array}{c}\text { Series of } \\
\text { experimental } \\
\text { material }\end{array}$} & $\begin{array}{c}\text { Melting temperature, K } \\
\text { Duration, } \mathrm{h}\end{array}$ & Heat treatment & $\begin{array}{c}\text { Characteristics of main } \\
\text { crystalline phase }\end{array}$ \\
\cline { 2 - 4 } & $1523-1723$ & Stage I 853-893 K, 4 h & Lithium disilicate \\
SL & $5-6$ & Stage II 973-1073 K, 4 h & vol $\%, 1 \mu \mathrm{m}$ \\
\hline SP & $1723-1873$ & Stage I 813-833 K, 4 h & $\begin{array}{c}\beta \text {-Spodumene } \\
80 \text { vol } \%, 1 \mu \mathrm{m}\end{array}$ \\
\hline
\end{tabular}




\section{Results and Discussion}

Petrographic analysis of experimental glasses of the SL series has shown that all specimens are formed on the base of colorless anisotropic eutectic melt. This fact is the evidence that the structure of model glasses contains nonuniformities of fluctuation type, highly evolved near the eutectic points where the simultaneous nucleation of two phases is possible.

This allows to conclude that during heat treatment of materials on the base of the synthesized glasses, the fine crystalline structure will be formed by directed crystallization.

The presence of lithium metasilicate is typical of SP glasses, recrystallization of which into lithium disilicate at preliminary heat treatment leads to $\beta$-spodumene crystallization at 1073-1123 K.

According to the data obtained by gradient thermal analysis, crystallization ability of SL and SP glasses is determined by the ratio of phase-forming components, type and amount of crystallization catalysts in their structure. For example, simultaneous presence of $\mathrm{TiO}_{2}$ and $\mathrm{ZrO}_{2}$ in experimental glasses leads to crystallization of phases in the amount of $30 \mathrm{vol} \%$ after melting. This may lead to further enlargement and growth of crystals during heat treatment, and as a result, to strength degradation of the structure and decrease of materials mechanical properties. Introduction of fluorite and titanium(IV) oxide to glasses of SP series provides the occurrence of crystalline phase in the amount of $20 \mathrm{vol} \%$ in their structure after cooling, with further formation of fine structure containing approximately $60 \mathrm{vol} \%$ of crystalline phase at heat treatment. Similar trend is observed for model glasses of SL series as well, which, along with the presence of $\mathrm{P}_{2} \mathrm{O}_{5}$ in their composition is an important prerequisite of phase separation with subsequent formation of glass-ceramic structure in conditions of lowtemperature heat treatment (Fig. 2).

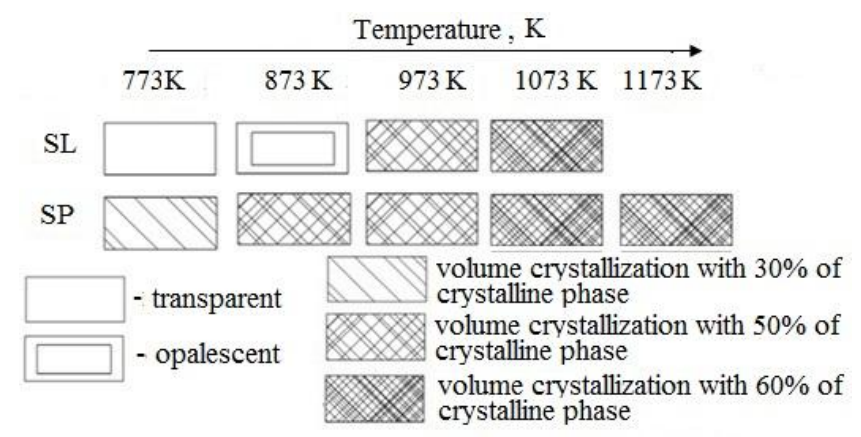

Fig. 2. Crystallization ability of model glasses

According to the DTA data for model glasses of SL and SP series, glass formation interval is determined by their melting characteristics and equal to $753-837 \mathrm{~K}$
(Fig. 3). Endothermic effect observed for these glasses within $573-653 \mathrm{~K}$ is related to elimination of residual stresses. Crystallization of glasses of SP series at $893 \mathrm{~K}$ is the evidence of possible formation of $\beta$-eucryptite. Upon the increase of the temperature to $1073 \mathrm{~K}$, conditions favorable to the occurrence of the peak characteristic to $\beta$-spodumene are created. For the glasses of SL series in the temperature interval of 893-973 K a high exothermic peak is observed, which is typical of lithium disilicate crystallization.

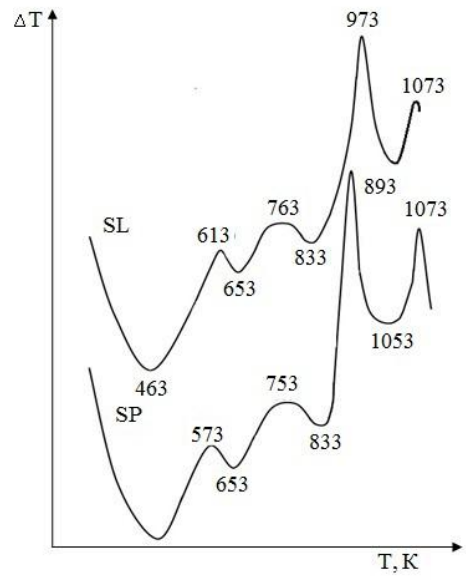

Fig. 3. Thermograms of model glasses

The choice of conditions of heat treatment for these glasses was based on generally accepted principles of designing glass-ceramics and considering the use of glass technology for their production [17]. The glass-ceramic materials of SL and SP series obtained under conditions of low-temperature treatment are characterized by volume fine crystallization of lithium disilicate or $\beta$-spodumene high-strength phases (Table 3).

It is due to the low-temperature heat treatment that the glass automatically "chooses" the metastable phases which are easily wetted by the glass, and as a result are strongly adhered to the glass. During long hightemperature exposures the recrystallization into stable phases takes place which will provide necessary performance characteristics of glass-ceramic material.

For the experimental materials of SL and SP series obtained after the two-stage heat treatment, the values of mechanical and thermal properties are typical of highstrength glass-ceramic materials (Table 4).

It has been established that formation of volumecrystallized fine structure of glasses that contain $\beta$-spodumene or lithium disilicate in the amount of $80 \mathrm{vol} \%$ provides elevated mechanical characteristics of the material. The combination of these characteristics along with low density will allow to use them as a base in developing materials used in composite armor elements, which will provide bullet and fragment protection and simultaneously act as a damper. 
Development of Glass-Ceramic High-Strength Material for Personal Armor Protection Elements 219

Table 4

Performance characteristics of developed glass-ceramic materials

\begin{tabular}{|c|c|c|c|c|c|c|}
\hline \multirow{2}{*}{$\begin{array}{c}\text { Series of } \\
\text { experimental } \\
\text { material }\end{array}$} & \multicolumn{3}{|c|}{ Mechanical characteristics } & \multirow{2}{*}{$\alpha \cdot 10^{7}, \mathrm{~K}^{-1}$} & \multirow{2}{*}{$\rho, \mathrm{g} / \mathrm{cm}^{3}$} \\
\cline { 2 - 7 } & $H, \mathrm{GPa}$ & $K_{l C}, \mathrm{MPa} \cdot \mathrm{m}^{0.5}$ & $H V, \mathrm{GPa}$ & $E, \mathrm{GPa}$ & & $2.38-2.40$ \\
\hline $\mathrm{SL}$ & $6.75-6.95$ & $2.85-3.0$ & $6.8-7.1$ & $84-90$ & $22.5-60.0$ & 2.0 \\
\hline $\mathrm{SP}$ & $8.33-9.08$ & $2.4-3.4$ & $8.28-8.67$ & $80-100$ & $10.0-22.4$ & $2.40-2.45$ \\
\hline
\end{tabular}

\section{Conclusions}

As a result of conducted investigations the methodological approach has been developed, which consists in determination of the complex of requirements to the created material and its functional role in the means of personal armor protection. The choice of initial lithium aluminosilicate $\quad \mathrm{R}_{2} \mathrm{O}-\mathrm{RO}-\mathrm{RO}_{2}-\mathrm{R}_{2} \mathrm{O}_{3}-\mathrm{LiF}-\mathrm{CaF}_{2}-\mathrm{P}_{2} \mathrm{O}_{5}-$ $\mathrm{SiO}_{2}$ system has been substantiated, the fields of synthesis of model glasses of SP (spodumene) and SL (on the base of lithium disilicate) in this system have been confined. Technological parameters of obtaining high-strength lightweight glass-ceramic materials which include temperature and duration of melting, as well as lowtemperature heat-treatment conditions needed to obtain the fine crystalline interconnected structure have been determined.

It has been found that developed glass-ceramic high-strength lightweight materials are characterized by low density of $2.38-2.45 \mathrm{~g} / \mathrm{cm}^{3}$ and high performance characteristics, viz. the value of microhardness of 6.75$9.08 \mathrm{GPa}$, Vickers hardness of $6.8-8.67 \mathrm{GPa}$, stress intensity of 2.4-3.4 MPa.m $\mathrm{m}^{0.5}$ and Young modulus of $80-$ $100 \mathrm{GPa}$ due to formation of volume-crystallized fine structure of glass containing $\beta$-spodumene or lithium disilicate in the amount of $80 \mathrm{vol} \%$.

Therefore, improvement of the effectiveness of composite armor may be achieved by the use of glassceramic materials in its body that simultaneously acts as energy-destructive and energy-damping layer, which will allow for weight and cost decrease of armor element while retaining its protective characteristics.

\section{References}

[1] Porwal P., Phoenix S.: Int. J. Fracture, 2005, 135, 217. https://doi.org/10.1007/s10704-005-3993-9

[2] Grigoryan V. (Ed.): Materialy i Zashchitnye Struktury dlya Lokalnogo i Individualnogo Bronirovaniya. RadioSoft, Moskva 2008.

[3] Cannillo V., Lusvarghi L., Manfredini T. et al:: J. Eur. Ceram. Soc., 2007, 27, 1935.

https://doi.org/10.1016/j.jeurceramsoc.2006.05.105

[4] Vlasov A., Emelianov Yu., Zilberbrand E. et al.: Fizika Tvyordogo Tela, 1999, 41, 1785.
[5] Darrant J., Thompson C.: Pat. GB 2379659, Publ. Mar. 19, 2003. [6] Maltsev V.: Metallografiya Promyshlennyh Tsvetnyh Metallov i Splavov. Kniga po Trebovaniyu, Moskva 2012.

[7] Zhitnyuk S., Makarov N., Guseva T.: Glass Ceram., 2014, 71, 6. https://doi.org/10.1007/s10717-014-9604-3

[8] Romashin A., Gaidachuk V., Karpov Ya. et al.: Radioprozrachnyie Obtekateli Letatelnyih Apparatov. Proektirovanie, Konstruktsionnyie Materialyi, Tehnologiya Proizvodstva, Ispyitaniya. Nats. Aerok. Univ. "Khark. Avits. Inst.", Kharkov 2003.

[9] Khalilev V., Suzdal' N.: Glass Ceram., 2004, 61, 42. https://doi.org/10.1023/B:GLAC.0000026771.19312.6e

[10] Loboda P., Bogomol Yu., Sysoev M. et al.: J. Superhard Mater., 2006, 28, 28.

[11] Vyshnyakov L., Mazna O., Neshpor O. et al.: Problemy Prochnosti, 2004, 6, 128.

[12] Gevorkyan E., Melnik O., Chishkala V.: Nanoscale Res. Lett., 2014, 9, 355. https://doi.org/10.1186/1556-276X-9-355

[13] Semchenko G.: Glass Ceram., 1997, 54, 149.

[14] Pogrebnyak A., Komarov F., Kaverina A. et al.: Techn. Phys., 2013, 58, 1688. https://doi.org/10.1134/S1063784213110200

[15] Suzdaltsev E., Rozhkova T., Zaichuk T. et al.: Pat. RF 2222505, Publ. Jan. 27, 2004.

[16] Tretiyakov O.; Chelpanov I.; Zhygailo B. et al.: Pat. UA 33014 A, Publ. Feb. 15, 2001.

[17] Tykachinskiy I., Fedorovskiy Ya. and Barshal B. (Ed.): Katalizirovannaya Kristallizatsiya Stekol. GIS, Moskva 1982.

Received: February 18, 2016 / Revised: M arch 03, 2016 / Accepted: N ovember 12, 2016

\section{РОЗРОБЛЕННЯ СКЛОКРИСТАЛІЧНИХ ВИСОКОМЩЦИХ МАТЕРІАЛІВ ДЛЯ ЕЛЕМЕНТІВ ІНДИВІДУАЛЬНОГО БРОНЕЗАХИСТУ}

Анотація. Встановлена перспективність використання склокристалічних високоміцних матеріалів для елементів індивідуального бронезахисту. Розроблено методологічний підхід, обтрунтовано вибір вихідної літійалюмосилікатної системи при одержанні високоміџних полегшених склокристалічних матеріалів. Досліджено область склоутворення в обраній системі та синтезовано склади модельних стекол. Вивчено особливості формування кристалічної структури у розроблених модельних стеклах за термічного оброблення. Розроблено високоміцні склокристалічні матеріали, щчо характеризуються високими експлуатаційними властивостями, та можуть бути використані при створенні сучасної композииійної броні.

Ключові слова: склокристалічний матеріал, літійалюмосилікатна система, високоміџний, механічні властивості, елемент індивідуального бронезахисту. 